\title{
Barriers to Implementation of Information and Communication (ICT) in Public Sudanese Secondary Schools: Teacher's Prospective
}

\author{
Abdelwahed Elsafi Elemam \\ Beijing Normal University, School of Education Technology, China \\ $\mathrm{Ph}:+86131269647272$ \\ E-mail: a_lsafi@hotmail.com
}

Received: January 29, 2016 Accepted: February 15, 2016 Published: February 28, 2016

doi:10.5296/jsr.v7i1.8956 URL: http://dx.doi.org/10.5296/jsr.v7i1.8956

\begin{abstract}
This study examines the current situation of ICT implementation at five public secondary schools in Sudan. The study adopted the quantitative method where a sample of five secondary schools was selected. A total of 40 secondary school teachers responded to the designed questionnaire. By using Statistic Package of Social Science (SPSS), the data was analyzed. The findings indicate that the ICT implementation at the five secondary schools was poorly achieved, and school teachers still have not acquired the necessary skills of ICT that enable them to implement ICT in classrooms. Further, the lack financial support, insufficient existence of computer labs, low internet connectivity, inadequate technical support and lack of time were main barriers that prevent the implementation of ICT in schools.
\end{abstract}

Keywords: ICT, Sudan, Secondary schools, Implementation Barriers, Teachers 


\section{Introduction}

Since 1980, the development of information and communication technology (ICT) and the increasing of people's awareness of the value of integrating ICT in education, a number of countries have carried out many initiatives to introduce ICT in their educational systems (Goktas, et al., 2013; Liu \& Pang, 2014). Many studies have been conducted on implementation of ICT in in different educational contexts (e.g. Laaria, 2013; Sultan \& Vian, 2015). Therefore, the implementation of ICT in education has played a significant role that changes the way of people's thinking and learning. Meanwhile, a number of studies show that the successful implementation of ICT in education make schools be more productive and efficient, and provide a better learning engagement experience (Leask \& Pachler, 2014). When used appropriately, ICT has high potential to improve teaching and learning, and well provide good opportunities for teachers to improve their ICT skills (Haddad \& Draxler, 2002; Oliver, 2005). However, the studies noted that the implementation of ICT in schools was not occurred automatically. The International Standards for Educational use of Technology (ISTE) organization, UNESCO and many worldwide educational organizations have created standards for integrating ICT in education, secondary schools in particular (Bernie, \& Charles, 2012 ). Hence the plenty of computer labs and abundance of ICT equipment are not enough to integrate ICT in schools in some developing countries. The implementation of ICT is strongly dependent on teachers' skills and experiences of how they use ICT in the daily classroom activities, based on national standards for ICT integration in education.

Despite the growth and development of ICT, there is a great evidence to show that the teachers still do not acquire the necessary skills that help them to be qualified and familiar with the application of ICT in daily teaching and learning activities (Salehi \& Zeinab, 2009). It seems that there are many barriers that prevent teachers of using ICT in an effective way in the classroom context.

Research studies have reported a number of ICT barriers when teachers trying to implement ICT in their classroom. Barrier is defined as a condition that does not support the achievement of objectives (Schoepp, 2005). This definition is applicable in this current study. Different categories of barriers have been reported by researchers to classify barriers that hinder teachers from implementation of ICT in education (Leggett \& Persichitte (1998). Some authors classify barriers to successful implementation of ICT for two categories: extrinsic and intrinsic barriers. Extrinsic factors are related to support, access to resources and time. While Extrinsic factors are concerned with attitudes, beliefs, practices and resistance towards ICT (Ertmer, 1999). Furthermore, other barriers could be related to insufficiency of funding, lack of resources to accesses, inadequate teachers' training, and lack of internet connectivity (Ch, at el, 2015). According to Laaria (2013) and Kipsoi et al (2012), the key barriers that prevent schools teachers from using ICT effectively are: a) lack of period for ICT training, b) poor models of practice while ICT training, and c) Poor schools administration. Following is a description of ICT in secondary schools in Sudan 


\subsection{ICT implementation in Sudanese secondary schools}

In Sudan, the government recognized the role of implementing ICT in secondary schools. This is seen through the government's national ICT plan that cares a lot for implementing ICT in secondary schools. According to the survey of ICT in education in Sudan by Hamdy (2007), the Sudanese government formulated the national ICT strategy that focuses on following areas:

- Technology infrastructures,

- Human resources development,

- Software industry development,

- Content (Arabic reservoir), and

- Geo-information (p.).

According to Samia (2015), The ICT plan for education was launched in 2002 to cover the development of schools curricula, teachers' training, managing and organizing educational institutions and supporting the idea of lifelong learning. In 2004, ICT was introduced in secondary schools curricula. A number of computers were installed in schools (around 50\% of secondary schools), at the average of 10 computers per school (Ahmed, 2015). However, the connectivity of internet is mainly through dial-up and ADSL at schools. In order to implement the strategy of ICTs, the Ministry of Education in Sudan has provided most secondary schools with computer labs in 2003. Furthermore, the computer labs of schools were established with internet connectivity (Safi, 2011). This shows that the Ministry of Education has planned for implementing ICT in education system. Despite these efforts, there is still a real gap of ICT knowledge in Sudanese schools and methods of implementation. Some recent studies related to ICT implementation at sudanese schools (e.g. Abdelwahed, 2014; Ahmed; 2015; Ezzelden, 2012) noted that the Sudanese secondary schools still have no effective practice for implementing ICT in education. As a result, this paper seeks to examine the current situation of Sudanese secondary schools and ICT barriers

\section{Study Objectives and Significance}

\subsection{Objectives of the Study}

The study aimed to realize the following objectives:

-To investigate the situation of ICT implementation in secondary schools in Sudan

-To explore the current barriers that prevent the implementation of ICT in secondary schools

\subsection{Significant of the Study}

The results of this study are expected to fill knowledge gap of implementation of ICT in schools. It is imperative to explore barriers during ICT implementation in secondary schools. The results would also be useful for policymakers, schools administrators, and teachers to 


\section{Macrothink}

achieve the goals of the ICT plan. The findings can be used as a framework for guiding and implementing ICT in secondary schools in Sudan.

\subsection{The Sample of the Study}

The sample of the study consists of 40 secondary school teachers, selected from 5 schools. Figure1 shows the demographic profile of secondary school teachers.

Figure 1. Profile of teachers

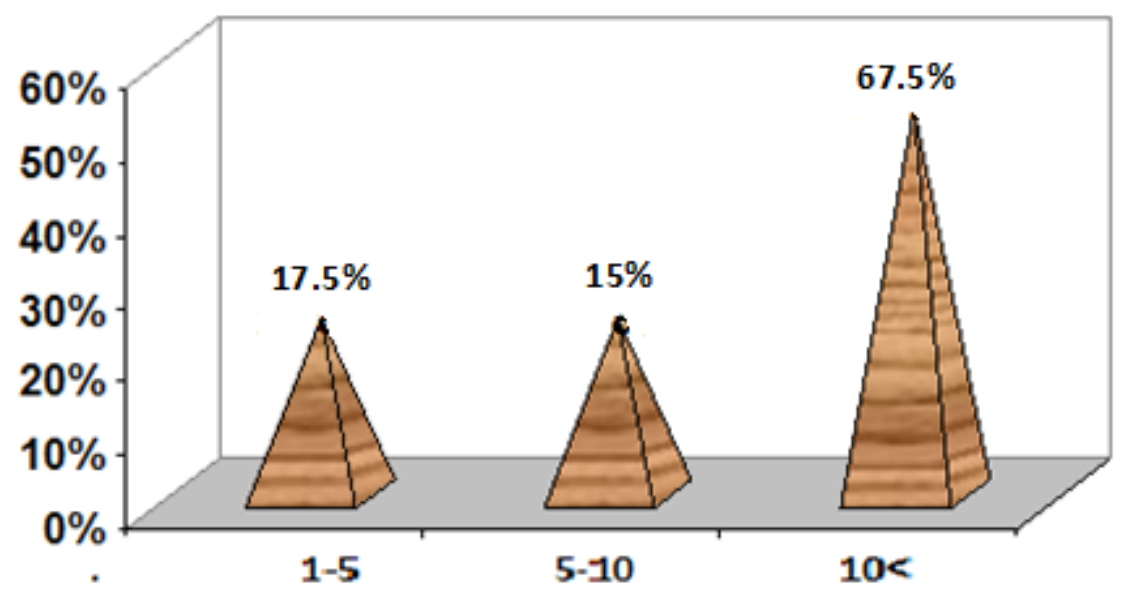

\section{Methodology of the Study}

To achieve the objectives of the study, a survey instrument was designed to gather information about the current situation of ICT and the barriers of implementation of ICT in five secondary schools. The study used the questionnaire to collect the data from school teachers. According to Johnson and Christensen (2014), a questionnaire is self- report datacollection instrument that each research participant fills out as part of a research study. The questionnaire was handed over to 40 teachers in five different secondary schools and all teachers filled in the questionnaire. After collecting the data from the respondents, the researcher started the analysis process that is shown below.

\section{Data analysis}

The data collected from the survey were analyzed using Statistic Package for Social Science (SPSS). For the description of the study, the frequencies and percentages are used to show demographic characteristics of responders, level of teachers related ICT skills and barriers of ICT implementation in schools

\section{Findings and Discussion}

In this section of the study, the findings will be presenting in tables and discussed according to specifics categories.

\subsection{The profile of responders}

As show in table1, the total of teachers response of the study was 40, at $25(67.9 \%)$ were male, while $15(32.1 \%)$ were female. The majority of teachers $27(67.5 \%)$ their teaching 


\section{Macrothink}

Journal of Sociological Research

ISSN 1948-5468

2016, Vol. 7, No. 1

experiences were between (greater than 10) years, and $7(17.5 \%$ ) of them their teaching experiences between (1-5) years, while 6(15\%) their teaching experience's between (5-10) years.

Table 1. Profile of teacher's respondent

\begin{tabular}{llll} 
Variable & Category & No & $\%$ \\
\hline Gender & Male & 25 & 67.9 \\
& Female & 15 & 32.1 \\
$\begin{array}{l}\text { Teaching } \\
\text { experience }\end{array}$ & $1-5$ & 7 & 17.5 \\
& $5-10$ & 6 & 15.0 \\
& Over 10 & 27 & 67.5 \\
\hline
\end{tabular}

5.2 Levels of ICT skills related teachers training.

As shown in table2, the application of word processing at 37(92.5\%) is most appropriate skilled by teachers. PowerPoint presentation result by $20(50 \%)$, data base result of 19 (47.5\%), and also the application of spreadsheet by 17(42.2\%) viewed that, most teachers need intensive practicing to master their skills. while the results of surfing internet (WWW) by $30(75 \%)$, and using E-mail by 35(87.5\%) viewed that teachers possess their skills. This results indicated that, the types of skills related ICT training (word processing, PowerPoint presentation, database, Excel and E-mail), was still not enough for implementation ICT in schools, therefore, in order to successful implementation of ICT in schools, the teachers need more practicing to be familiar with ICT and currying out into their classroom activities. 
Table 2. Levels of ICT skills.

\begin{tabular}{lcc}
\hline The types of teachers ICT skills & NO & $\%$ \\
\hline Word processing & 37 & 92.5 \\
PowerPoint presentation & 20 & 50 \\
Data base (Access) & 19 & 47.5 \\
Spreadsheet (Excel) & 17 & 42.2 \\
Internet (WWW) & 30 & 75 \\
E-mail & 35 & 87.5 \\
\hline
\end{tabular}

\subsection{Barriers of ICT implementation in schools}

The result of this section indicated that, all ICT barriers that effect the implementation of ICT in schools, noted in previous studies was also found in this study of province of Bahry. As shown in table3, the result of $34(85 \%)$ Insufficient of computer labs, the responders at $32(80 \%)$ lack of teacher training of using ICT and $29(72.5 \%)$ Inadequate of technical support as well as $30(75 \%)$, lack of time and $30(75 \%)$ difficult to integrate ICT, were all most the main barriers that prevent teachers of implementing ICT in their schools. And also $25(62.5 \%)$ of teachers their responders noted that, Inadequate of computers maintenance was one of barriers that prevent teachers from using ICT in successful way as creative teaching tool. However the results of this section agreed with others studies conducted in different countries around the world, (Kipsoi et al .2012; Khan et al, 2012; Zyad, 2016; Abdelwahed, 2014). Form the results it seem that, there is relation between many barriers such as lack of teacher Training of using ICT and technical support. Teachers cannot use ICT tools appropriately in classroom, because they were poorly trained. Thus teachers always need technical support while trying to use ICT during every day teaching activities, while technical assistance itself was not quit enough to provide them with successful way to integrate information and communication technology in the teaching process. Another example is that, the relation between Inadequate of computers maintenance and Inadequate of technical support. Keep of computers maintenance are one of the key factors that help teachers to do effectively while using technology in the classroom, so that when the one of computers breakdown, it would be very importance fixed by technician staff. 
Table 3. Barriers related implementation of ICT in schools

\begin{tabular}{lcc}
\hline Barriers & No & $\%$ \\
\hline Lack of teacher Training of using ICT & 32 & 80 \\
Inadequate of technical support & 29 & 72.5 \\
Lack of funding & 22 & 55 \\
Insufficient of computer labs & 34 & 85 \\
Inadequate of computers maintenance & 25 & 62.5 \\
Low of internet connectivity & 19 & 74.5 \\
Difficult to integrate ICT & 30 & 75 \\
lack of resources to accesses & 32 & 80 \\
Lack of time & 30 & 75 \\
\hline
\end{tabular}

To conclude, it can be reported that:

- The teachers are poorly knowledgeable about ICT using in teaching and learning process, another problem related ICT training is that, the level of training that teachers acquired about ICT was mostly for general knowledge and skill, not for integrating ICT into the daily learning activates.

- The lack of time was main barrier against the implementation of ICT in secondary schools.

- Lack of ICT resources are becoming one of the main hinder implementation of ICT in schools.

- Insufficient of computer labs, Low of internet connectivity, Inadequate of technical support and lack of time are also hinder to implement ICT in schools.

- The application of word processing was being one of the basic ICT skills that most of schools teachers trained and mastered.

Despite of the initiatives of the ministry of education in Sudan to formulate ICT policy for education system and provides many schools with ICT equipment's, but the actual situation 


\section{MInstitute ${ }_{\text {Mnk }}^{\text {Macrothin }}$}

of implementation of ICT in Sudanese secondary schools show that, was still has many different barriers that hinder implementation of ICT in secondary schools.

\section{Recommendations}

Based on the results of the study, the study formulated the following recommendations:

- The effectiveness of implementation of ICT in Sudanese secondary schools, require policy makers teachers, all stakeholders and authorities, should be aware of importance of implementation of ICT in education, and understand beneficial of ICT in developing teaching and learning.

- The implementation of ICT in schools should be according to the ICT policy plan for education, and it would follow the standard of ICT integration in education posted by UNICSO.

- In order to overcome of ICT berries related teachers training, school principals and teachers need to collaborate and help each other to reduce ICT barriers among schools.

- To offer more funding, schools need to dedicate money from the students' fees, parent's and other external funding support, to face needs of buying new computers, computers maintenance and others ICT requirements.

- $\quad$ The Ministry of education in Sudan must emphasize on teachers training as main issue, and make it in the first of priorities.

\section{Conclusion}

The purposes of this study are to examine the current situation of ICT and determine barriers related ICT implementation in Sudan secondary schools - Province of Bahry. Since the implementation of ICT in schools it doesn't happen randomly, it depend on many different factors that brings together to make ICT in schools context. In this study it appears that there are many different barriers against successful implementation of ICT in Sudanese secondary schools - Province of Bahry. Lack of computer labs, lack of teachers training for using ICT and lack of resources to access were main barriers against implementing ICT. However the situation of ICT in schools doesn't help to implement ICT in education.

\section{References}

Abdelwahed, E. \& Xiaohong,Y. (2014). Informationization of education and teacher professional development in Sudan: Challenges and policy issues. International journal of Science Commerce and Humanities, 2 (2), 162-168. http://www.ijsch.com/journaluk/images/frontImages/Informationization_of_Education _and_Teacher_Professional_Development_in_Sudan-_Challenges_and_Policy_Issues. pdf 


\section{Macrothink}

Journal of Sociological Research

ISSN 1948-5468

2016, Vol. 7, No. 1

Ahmed, A. (2015). A preliminary study of ICT's infrastructure and pedagogical practices for technology integration in Sudanese Secondary schools. Research Gate 12(7), 1-54.

Bernie, T. \& Charles, F. (2009). 21ST Century Skills; learning for life in our times .library of Congress.

British Educational Communications and Technology Agency (2004). A review of the research Literature on barriers to the uptake of ICT by teachers. Coventry: BECTA.

Ch, P. latina \& P.Srika . (2015). Barriers to the use of Information and Communication

Technology (ICT) in Secondary schools: teachers prospective. Journal of Management Research.

7(2).190-208.https://www.questia.com/library/journal/1P3-3660148911/barriers-to-the-use-of -information-and-communication

Charalambos ,V. Michalinos, Z. \&Gene, V.(2009). ICT for Education Development \& Social

Justice. Charlotte, NC: Information Age Publishing, Inc.

Ertmer, P.A. (1999). Addressing first -and second- order barriers to change: Strategies for technology integration. Education Technology Research and Development, 47(4), 47-61.

Ezzelden, I. (2012). Sudanese Secondary School Teachers Readiness Towards E-learning: Information and communication technology (ICT). http://pdfsr.com/isbn/9783659262944

Haddad, W \& Draxler, A. (2002). Technologies for Education. Paris. UNESCO and the Academy

for Educational Development.

Hamdy (2007). Survey of ICT and education in Africa: Sudan Country Report. Online accessed 25

December 2015 http://www.infodev.org/infodev-files/resource/InfodevDocuments_430.pdf Johnson, B., \& Christensen, L. (2014). Educational Research: Quantitative, Qualitative, and Mixed Approaches, Fourth Edition. SAGE.

Kipsoi, E., Changach, J. \& Sang, H. (2012).Challenges facing adoption of implementation of communication technology (ICT) in educational management in schools in Kenya. Journal of Sociological research. 3(1).18-28.

http://www.macrothink.org/journal/index.php/jsr/article/view/1882

Khan, M., Hasan, M. \& Clement, C. (2012). Barriers to the introduction of ICT into education in 
developing countries: the example of Bangladesh. International Journal of Instruction, 5 (2), 62-80. http://www.e-iji.net/dosyalar/iji_2012_2_4.pdf

Laaria, M. (2013). Leadership challenges in the implementation of ICT in public secondary schools, Kenya, Journal of education and learning. 2(1). 32-43.

http://www.ccsenet.org/journal/index.php/jel/article/viewFile/22772/15105

Leask, M. \& Pachler, N. (2014). Learning to teach using ICT in secondary schools. A Companion to school experience .Routledge.taylor and Francis

Leggett, W. P. \& Persichitte, K. A. (1998). Blood, sweat, and TEARS: 50 years of technology Implementation obstacles. TechTrends, 43(3), 33-36.

Liu, X. \& Pang, J. (2014). Early Childhood teachers' perceived barriers to ICT integration in teaching: a survey study in Mainland China. J. Comput. Educ.

Oliver, R. (2005). The role of ICT in higher education for the 21st century: ICT as a change agent for education. http://citeseerx.ist.psu.edu/viewdoc/summary?doi=10.1.1.83.9509

Safi, A. (2011).Strategic plan for implementation ICT in Sudanese Secondary School: Case of Bahry Province. M.Sc Dissertation of Computer Integrated Education. Sudan University of Science and Technology. Not Published.

Samia, N. (2015). Overview of Sudanese Economy and the Status of ICT in Sudan. Available on.

http://link.springer.com/chapter/10.1007\%2F978-3-319-13999-9_2

Schoepp, K. (2005). Barriers to technology integration in a technology-rich environment. Learning And teaching in higher education: Gulf perspectives, 2(1), 1-24.

http://www.zu.ac.ae/lthe/vol2no1/lthe02_05.pdf

Sultan, A. \& Vian, A. (2015). Success factors for ICT implementation in Saudi secondary schools: From the perspective of ICT directors, head teachers, teachers and students. IJEDICT, (11)1, 36-54

Goktas, Y., Gedik, N., \& Baydas, O. (2013). Enablers and barriers to the use of ICT in primary schools in Turkey: A comparative study of 2005-2011. Computers \& Education. 212-222.

Zyad, H. (2016). Integrating Computers in the Classroom: Barriers and Teachers' Attitudes. International Journal of Instruction, 9 (1), 66-78.

Salehi, H. \& Zeinab,S. (2012).Challenges for Using ICT in Education: Teachers'Insights. International Journal of e-Education, e-Business, e-Management and e-Learning, 2(1). 


\section{Macrothink \\ Journal of Sociological Research \\ ISSN 1948-5468 2016, Vol. 7, No. 1}

http://www.ijeeee.org/Papers/078-Z00061F10037.pdf

\section{Copyright Disclaimer}

Copyright for this article is retained by the author(s), with first publication rights granted to the journal.

This is an open-access article distributed under the terms and conditions of the Creative Commons Attribution license (http://creativecommons.org/licenses/by/3.0/). 